\title{
In Vitro Antileishmanial Properties of Neutron-Irradiated Meglumine Antimoniate
}

\author{
Samanta Etel Treiger Borborema ${ }^{1 *}$, Heitor Franco de Andrade Junior ${ }^{3}$, João Alberto Osso \\ Junior $^{2}$ and Nanci do Nascimento ${ }^{1}$ \\ ${ }^{1}$ Laboratório de Biologia Molecular; ${ }^{2}$ Centro de Radiofarmácia; Instituto de Pesquisas Energéticas e Nucleares \\ (IPEN/CNEN - SP); Av.Professor Lineu Prestes 2242; samanta@usp.br; jaosso@ipen.br; 05508-000; São Paulo - \\ SP - Brasil. ${ }^{3}$ Laboratório de Protozoologia; Instituto de Medicina Tropical de São Paulo (IMT-SP); Rua Dr. Enéas \\ de Carvalho Aguiar 470; hfandrad@usp.br; 05403-000 - São Paulo - SP - Brasil
}

\begin{abstract}
Pentavalent antimony, as meglumine antimoniate (Glucantime $\AA$ ) or sodium stibogluconate (Pentostam $($ ), is the main treatment for leishmaniasis, a complex of diseases caused by the protozoan Leishmania, and an endemic and neglected threat in Brazil. Despite over half a century of clinical use, their mechanism of action, toxicity and pharmacokinetic data remain unknown. The analytical methods for determination of antimony in biological systems remain complex and have low sensitivity. Radiotracer studies have a potential in pharmaceutical development. The aim of this study was to obtain a radiotracer for antimony, with suitable physical and biological properties. Meglumine antimoniate was neutron irradiated inside the IEA-RI nuclear reactor, producing two radioisotopes $122 \mathrm{Sb}$ and ${ }^{124} \mathrm{Sb}$, with high radionuclidic purity and good specific activity. This compound showed the same antileishmanial activity as the native compound. The use of the radiotracers, easily created by neutron irradiation, could be an interesting tool to solve important questions in antimonial pharmacology.
\end{abstract}

Key words: Meglumine antimoniate, leishmaniasis, Leishmania (L.) chagasi, radiotracer

\section{INTRODUCTION}

Leishmaniasis is a complex of diseases caused by the protozoan parasite of the genus Leishmania, transmitted by the phlebotomine sand fly vector. Human leishmaniasis is distributed worldwide, but occurs mainly in the tropics and subtropics, with a prevalence of 12 million cases, causing diseases ranging from skin lesions in cutaneous leishmaniasis (CL) to a progressive and frequently fatal hepatosplenomegaly in visceral leishmaniasis (VL) (Croft and Coombs, 2003). Co-infection with HIV makes VL a priority for the World Health Organization (Guerin et al., 2002).
Pentavalent antimonials, such as meglumine antimoniate (Glucantime $\left.{ }^{\circledR}\right)$ or sodium stibogluconate (Pentostam $®$ ), are the main drugs recommended in the treatment of all forms of leishmaniasis (Murray, 2001). Other alternative drugs used in the treatment are pentamidine and amphotericin B, but their use has been limited by high toxicity and cost (Singh and Sivakumar, 2004). Despite several gaps in the knowledge of action, toxicity and pharmacokinetic parameters, pentavalent antimonials have been used for over 60 years (Roberts et al., 1998) and the definition of its pharmacokinetic profile may suggest a better therapeutic protocol for doses, administration

\footnotetext{
${ }^{*}$ Author for correspondence
} 
interval and duration of the antimonial therapy, reducing resistance, relapse and severe side effects.

The analytical methods for determination of the amount of antimony in biological systems remain complex and have low sensitivity (Rath et al., 2003). Radiotracer studies performed on animals have the potential to play a major role in pharmaceutical development, pharmacological studies and basic biochemistry research (Meikle and Eberl, 2001). Therefore, the aim of this study was to obtain a radiotracer, by neutron irradiation of Glucantime ${ }^{\circledR}$, resulting in radioactive antimony salts, with biocompatibility and the same antileishmanial activity as the native compound.

\section{MATERIALS AND METHODS}

\section{Production and analysis of antimony radiotracer}

For standardization, samples of $0.5-0.8 \mathrm{~mL}$ of meglumine antimoniate (Glucantime ${ }^{\circledR}$; Aventis, S.P., Brazil, $81 \mathrm{mg} \mathrm{Sb} / \mathrm{mL}$ ) were sealed in quartz ampoules and irradiated at a thermal neutron flux of $1 \times 10^{13} \mathrm{n} / \mathrm{cm}^{2}$.s, for 20,15 and 7 minutes, inside the IEA-R1 nuclear reactor (IPEN-CNEN/SP). Radionuclidic purity was determined by $\gamma$ spectrometry, using an HPGe detector (Canberra Company) coupled to the Geniepec program. Radioactive concentration was also measured with the same system after efficiency calibration with standard $60 \mathrm{Co}, 137 \mathrm{Cs}$ and $152 \mathrm{Eu}$ sources. UVvisible spectrometry Ultrospec 3000 (Pharmacia Biotech) was used for the chemical determination, of samples of the neutron-irradiated meglumine antimoniate (IMA) and non-neutron-irradiated meglumine antimoniate (NMA) by scanning the spectrum from 200 to $700 \mathrm{~nm}$,

\section{Determination of the $50 \%$ Effective Concentration (EC50)}

The antileishmanial activity against promastigotes was determined as described elsewhere (Tempone et al., 2005). Cold irradiated and non-irradiated meglumine antimoniate were diluted in M199 medium supplemented with $10 \%$ FBS, at different concentrations and incubated with $1 \times 10^{6} L$. (L.) chagasi promastigotes (M6445 strain)/well in 96well micro plates. The plates were incubated for $24 \mathrm{~h}$ at $24{ }^{\circ} \mathrm{C}$ and the viability of promastigotes was verified by the MTT assay. The sigmoid dose- response analysis was accomplished using Graph Pad Prism 3.0 software.

\section{Cytotoxicity assay.}

RAW 264.7 (ATCC TIB-71) cells were seeded in 96-well micro plates at $4 \times 104 /$ well. Drugs were serial diluted in RPMI - PR-1640 with 10\% FBS medium at different concentrations. The plates were incubated for $48 \mathrm{~h}$ at $37{ }^{\circ} \mathrm{C}$ in a $5 \% \mathrm{CO}_{2}$ incubator. The viability of the macrophages was determined by the MTT assay. The sigmoid doseresponse analysis was performed using Graph Pad Prism 3.0 software.

\section{Antileishmanial activity against intracellular amastigote.}

Macrophages were collected from the peritoneal cavity of female BALB/c mice by washing with RPMI - PR-1640 medium with 10\% FBS. They were then seeded at $4 \times 105 /$ well into 24 -well plates containing glass cover slips for a period of $2 \mathrm{~h}$ at $37{ }^{\circ} \mathrm{C}$ in a humidified $5 \% \mathrm{CO}_{2} 95 \%$ air incubator for attachment. Non-adherent cells were removed by one-step washing with medium and the subsequent incubation was performed for $24 \mathrm{~h}$ undert the same conditions. L. (L.) chagasi amastigote (M6445 strain) were obtained from the spleen of the golden hamster by differential centrifugation and added at a ratio of 1:10 (macrophage/amastigote) and incubated for $18 \mathrm{~h}$. Macrophages were treated with cold irradiated and non-neutron-irradiated meglumine antimoniate during $96 \mathrm{~h}$. Samples without drugs were used for control (100\% infected). At the end of the assay, macrophages were fixed with methanol and stained with Giemsa. The parasite burden was verified as the number of infected macrophages in a total of 400 cells. The data were analyzed by a sigmoid dose-response curve using Graph Pad Prism 3.0 software.

\section{RESULTS AND DISCUSSION}

The neutron irradiation of meglumine antimoniate in a nuclear reactor produced two radioisotopes of antimony: ${ }^{122} \mathrm{Sb}$ and ${ }^{124} \mathrm{Sb}$. High radionuclidic purity was verified, where ${ }^{122} \mathrm{Sb}\left(\mathrm{t}_{1 / 2}=2.7\right.$ days $)$ gamma peaks were observed in $563.99 \mathrm{keV}$ $(69.3 \%)$ and $692.94 \mathrm{keV}(3.78 \%)$ and ${ }^{124} \mathrm{Sb}\left(\mathrm{t}_{1 / 2}=\right.$ 60.2 days) in $602.66 \mathrm{keV}$ (97.8\%), $645.77 \mathrm{keV}$ 
(7.38\%), $668.87 \mathrm{keV}, 709.26 \mathrm{keV}(1.35 \%), 713.73$ $\mathrm{keV}(2.40 \%), 722.75 \mathrm{keV}(10.76 \%), 790.46 \mathrm{keV}$ (0.74\%), $968.31 \mathrm{keV}$ (1.8\%), $1045.15 \mathrm{keV}$ (1.84\%), $1368.43 \mathrm{keV}(2.62 \%)$ e $1691.51 \mathrm{keV}$ (47.34\%). Activity at the end of irradiation was $33.2 \mathrm{MBq}(0.897 \mathrm{mCi})$ of ${ }^{122} \mathrm{Sb}$ and $0.77 \mathrm{MBq}$ $(0.021 \mathrm{mCi})$ of ${ }^{124} \mathrm{Sb}$, corresponding to a specific activity of $22.12 \mathrm{MBq},{ }^{122} \mathrm{Sb} / \mathrm{mL}$ of meglumine antimoniate $(0.598 \mathrm{mCi} / \mathrm{mL})$, and $0.52 \mathrm{MBq}$ ${ }^{124} \mathrm{Sb} / \mathrm{mL}$ of meglumine antimoniate $(0.014$ $\mathrm{mCi} / \mathrm{mL})$. After analysis of the IMA, the samples neutron-irradiated for a longer period (20 and 15 minutes) showed an intense color change, with spectrophotometric modifications (data not shown) and with physical-chemical alterations, as compared to NMA. Samples neutron-irradiated for seven minutes presented very little absorbance at $300 \mathrm{~nm}$, with a slight color change, probably due to the meglumine polymer formation. The same effect was verified when the product was exposed to unsuitable conditions of temperature, lighting, and bad storage conditions (Romero et al., 1996).

During the in vitro assessment of biological activity of the meglumine antimoniate, neutron irradiated for seven minutes, the same effectiveness against amastigotes, tested in vitro with $L$. (L.) chagasi infected macrophage (Fig. 1), as with the native product, was observed, despite some enhancement of activity against promastigotes or living cells (Table 1).

It has been suggested that $\mathrm{Sb}^{\mathrm{V}}$ is a prodrug and is intracellularly reduced to trivalent form $\left(\mathrm{Sb}^{\mathrm{III}}\right)$, the active form of the drug, at or near the site of action. The antileishmanial activity of $\mathrm{Sb}^{\mathrm{V}}$ has been found to be dependent on its reduction to $\mathrm{Sb}^{\mathrm{III}}$ inside the parasite (Shaked-Mishan et al., 2001). The greater susceptibility of $\mathrm{Sb}^{\mathrm{V}}$ to intracellular amastigotes than promastigotes suggests that the reductive activation of the drug occurs within the intracellular amastigotes (Yan et al., 2003).

The meglumine antimoniate, neutron irradiated for seven minutes, showed high radionuclidic purity, good specific activity, maintenance of the biological activity and suitable physiological characteristics, allowing its use in biodistribution studies, It furnished evidence to advance the pharmacokinetic study for antileishmanial therapy. The use of neutron irradiation for developing antimony radiotracers could be an interesting tool for solving important questions in antimonial pharmacology.

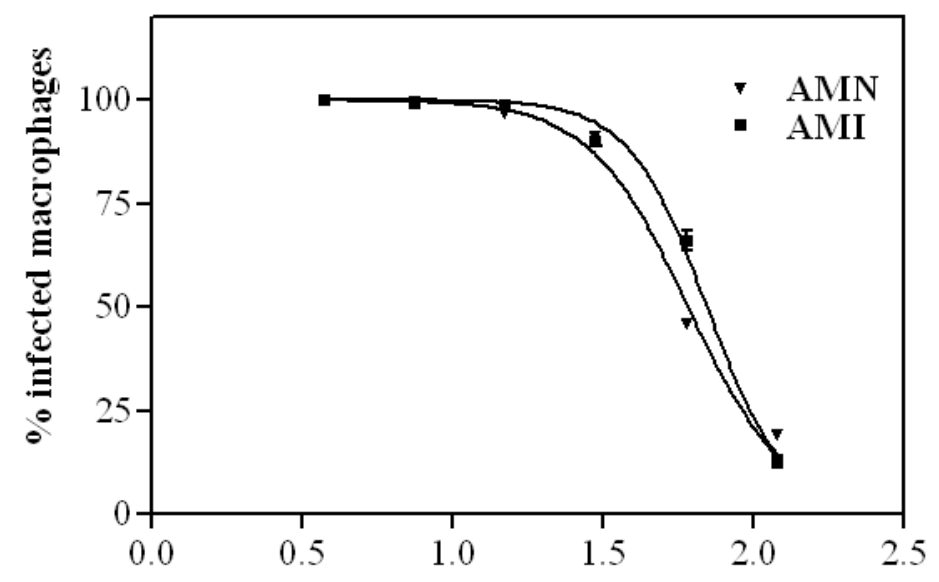

$\log$ of concentration $\mu \mathrm{g} / \mathrm{mL}$ )

Figure 1 - Determination of $\mathrm{EC}_{50}$ of IMA and NMA against L. chagasi-infected macrophages. Macrophages were treated for $96 \mathrm{~h}$ at $37^{\circ} \mathrm{C}$ with drugs, and the number of infected macrophages in Giemsa-stained glass cover slips was determined by light microscopy. Dose-response curves were obtained with GraphPad Prism 3.0 software. Data are mean and standard deviation. IMA = neutron-irradiated meglumine antimoniate $\left(1 \times 10^{13} \mathrm{n} / \mathrm{cm}^{2} . \mathrm{s}, 7\right.$ minutes $)$; NMA $=$ non-neutron-irradiated meglumine antimoniate 
Table 1 - Effectivity of the neutron-irradiated meglumine antimoniate in L. (L.) chagasi promastigotes, macrophages infected with $L$. (L.) chagasi amastigotes and mammalian cells. IMA= neutron-irradiated meglumine antimoniate (thermal neutron flux of $1 \times 10^{13} \mathrm{n} / \mathrm{cm}^{2}$.s, for 7 minutes); NMA= non-neutron-irradiated meglumine antimoniate. EC 50\% (IC95\%), $(n=2)$.

\begin{tabular}{ccc}
\hline DRUG & IMA & NMA \\
\hline CELL & & \\
\hline L. (L.) chagasi promastigotes & $20.94 \mathrm{mg} \mathrm{Sb} / \mathrm{mL}$ & $41.73 \mathrm{mg} \mathrm{Sb} / \mathrm{mL}$ \\
& $(16.73-26.2)$ & $(32.67-53.30)$ \\
L. (L.) chagasi amastigotes & $70.62 \mu \mathrm{g} \mathrm{Sb} / \mathrm{mL}$ & $61.14 \mu \mathrm{g} \mathrm{Sb} / \mathrm{mL}$ \\
& $(64.22-77.67)$ & $(52.68-70.96)$ \\
Mammalian cells & $1.43 \mathrm{mg} \mathrm{Sb} / \mathrm{mL}(0.99$ & $3.56 \mathrm{mg} \mathrm{Sb} / \mathrm{mL}$ \\
& $-2.07)$ & $(2.37-5.35)$ \\
\hline
\end{tabular}

\section{ACKNOWLEDGEMENTS}

This work was supported by the CNPq (SETB fellowship Masters Program Proj. 134047/2003-6) and (LIM-HC-FMUSP-49).

\section{RESUMO}

Os antimoniais pentavalentes, como o antimoniato de meglumina (Glucantime ${ }^{\circledR}$ ) ou estibogluconato de sódio (Pentostam $\AA$ ), são o principal tratamento para a leishmaniose, um complexo de doenças causadas pelo protozoário parasita Leishmania, uma doença endêmica e negligenciada no Brasil. Apesar do seu uso clínico por mais de meio século, seu mecanismo de ação, toxicidade e dados de farmacocinética permanecem desconhecidos. Os métodos analíticos para determinação de antimônio em sistemas biológicos são complexos e apresentam baixa sensibilidade. Estudos utilizando radiotraçadores têm papel potencial no desenvolvimento farmacológico. O objetivo deste estudo foi desenvolver um radiotraçador de antimônio, com propriedades físicas e biológicas adequadas. $\mathrm{O}$ antimoniato de meglumina foi irradiado por nêutrons no reator nuclear IEA-R1, produzindo dois radioisótopos: ${ }^{122} \mathrm{Sb}$ e ${ }^{124} \mathrm{Sb}$, com alta pureza radionuclídica e boa atividade específica. Este composto mostrou atividade antileishmania similar ao fármaco não irradiado. $\mathrm{O}$ uso de radiotraçadores, facilmente produzidos por irradiação por nêutrons pode ser um importante instrumento para elucidar questões sobre a farmacologia dos antimoniais.

\section{REFERENCES}

Croft, S. L. and Coombs, G. H. (2003), Leishmaniasis current chemotherapy and recent advances in the search for novel drugs. Trends in Parasitology, 19, 502-508.

Guerin, P. J.; Olliaro, P.; Sundar, S.; Boelaert, M.; Croft, S. L.; Desjeux, P.; Wasunna, M. K. and Bryceson, A. D. (2002), Visceral leishmaniasis: current status of control, diagnosis, and treatment, and a proposed research and development agenda. The Lancet Infectious Diseases, 2, 494-501.

Meikle S. R.; Eberl S. and Iida, H. (2001), Instrumentation and methodology for quantitative pre-clinical imaging studies. Current Pharmaceutical Design, 7, 1945-66.

Murray H. W. (2001), Clinical and experimental advances in treatment of visceral leishmaniasis. Antimicrobial Agents and Chemotherapy, 45, 2185-2197.

Rath, S.; Trivelin, L. A.; Imbrunito, T. R.; Tomazela, D. M.; Jesus, M. M.; Marzal, P. C.; Andrade Jr., H. F. and Tempone, A. G. (2003), Antimoniais empregados no tratamento da leishmaniose: estado da arte. Quimica. Nova, 26, 550-555.

Roberts, W.; Mcmurray, W. J. and Rainey, P. M. (1998), Characterization of the antimonial antileishmanial agent meglumine antimoniate (glucantime). Antimicrobial Agents and Chemotherapy, 42, 1076-1082.

Romero, G. A. S.; Oliveira, M. R. F.; Dalmo, C. and Marsden, P. D. (1996), Características físico-químicas do antimoniato de meglumina em diferentes condições de armazenamento. Revista da Sociedade Brasileira de Medicina Tropical, 29, 461-465.

Shaked-Mishan, P.; Ulrich, N.; Ephros, M. and Zilberstein, D. (2001), Novel intracellular $\mathrm{Sb}^{\mathrm{V}}$ reducing activity correlates with antimony susceptibility in Leishmania donovani. The Journal of Biological Chemistry, 276, 3971-3976. 
Singh, S. and Sivakumar, R. (2004), Challenges and new discoveries in the treatment of leishmaniasis. Journal of Infection and Chemotherapy, 10, 307-315.

Tempone, A. G..; Borborema, S. E. T.; Andrade Jr., H. F.; Gualda, N. C. A.; Yogi, A.; Carvalho, C. S.; Bachiega, D.; Lupo, F. N.; Bonoto, S. V. and Fischer, D. C. H. (2005), Antiprotozoal activity of Brazilian plant extracts from isoquinoline alkaloid-producing families. Phytomedicine, 12, 382-390.

Yan, S.; Li, F.; Ding, K. And Sun, H. (2003), Reduction of pentavalent antimony by tripanothione and formation of a binary and ternary complex of antimony (III) and trypanothione. Journal of Biological and Inorganic Chemistry, 8, 689-697. 